\title{
The Effect of Price, Ease of Transaction, Information Quality, Safety, and Trust on Online Purchase Decision
}

\author{
Rizqi Maulana I Akbar*, Raden Andi Sularso, Ketut Indraningrat \\ Department of Management, Faculty of Economics and Business, University of Jember \\ Jln. Kalimantan 37, Jember 68121 \\ E-mail: rizq.maulana15@gmail.com
}

\begin{abstract}
This research aims to analyze the effect of price, ease of transaction, information quality, safety, and trust on online purchase decision. Applying purposive sampling technique, the sample was students of the Department of Management, Faculty of Economics and Business, University of Jember that consisted of 100 respondents. This study used quantitative data sourced from primary data. Data were analyzed using multiple linear regression. Results showed that, both partially and simultaneously, the variables of price, ease, information quality, safety, and trust had a significant positive effect on online purchase decision.
\end{abstract}

Keywords: Price, Ease of Transaction, Information Quality, Safety, Trust, Online Purchase Decision.

\section{Introduction}

Technology development occurs in various sectors of transportation and electronic communication creating the new world dimension called the cyberspace or virtual world. The result of this technology development is the shift of lifestyle that more people attached to gadgets and having the tendency to engage in online activities, e.g., online shopping as the new shopping culture. The era of globalization is an era where geographical boundaries between countries are no longer an obstacle in the communication and interaction process between individuals. This is increasingly apparent when we associate with the Internet as one of its mediums. Internet has an important role in introducing human to the cyberspace. Advances in technology have helped some parties in conducting their business activities. These technology advances also overcome obstacles in terms of distance, limited information, and limited product knowledge. The companies can use the strategy of utilizing marketing media through the Internet. According to Kertajaya (2003: 149), to win a competition, a company should not only rely on service and quality or simply focusing on the strength of the context.

The students of University of Jember come from various groups with different social and economic backgrounds. These differences will influence them in making online purchases. Engaging in online transaction will facilitate the buyers in purchase process. For example, students could choose desired products online in a flexible time. They do not have to visit the physical or offline stores. According to Kotler and Keller (2011: 67) price is an element of the marketing mix that generates revenue but also costs. Based on the opinion of several researchers, it can be concluded that price is an important element, especially to obtain profits for the sustainability of the company. Moreover, price is also described as a value that determined in the exchange process of goods and services between buyers and sellers. According to Jogiyanto (2007: 115), ease is defined as the extent to which one believes that using a technology will be more effortless. Ease will have an impact on consumer's behavior, i.e., the better consumer's perception of the ease of using the system, the better the level of information technology utilization. When doing online transaction for the first time, prospective buyers will usually experience some difficulties and obstacles, especially about the safety aspect since consumers still do not fully understand the procedures of online transaction. This will lead to the tendency of buyers to discourage their intention to shop online.

The development of information flow has now brought changes to each individual or group including in online shopping activities. Luthfiya (2014) state that the information presented in an online shop or online store can include information related to products and goods and services available in the online shop. In the online shopping process, information search begins when consumers assume that these needs can be met by buying and consuming a product.The information offered must be useful and must be relevant to actual conditions as the basis to predict the real quality and usefulness of products and services. In addition, information must also be up-to-date to satisfy consumers' needs for the desired product information.

According to Park and Kim (2006: 81), safety in online shopping is the ability of online stores in controlling and maintaining the safety of data transactions. Park and Kim also stated that this safety guarantee plays an important role in the formation of trust as well as to avoid the misuse of personal information for certain interests. Unfortunately, the rapid technology development is also in line with the development of Internet-based fraud modes, especially in online sales. Trust is defined as a willingness to rely on a trustworthy seller and the online transaction and trust arises when those involved in online transaction have received confirmation from the other party, as well as the willingness and ability to fulfill their obligations (Antarwiyati, 2010: 5). In the long-term period, the most significant obstacle of Internet success as a commercial medium in the market is the lack of consumer trust towards the Internet and online sellers (Jarvenpaa, Tractinsky, and Vitale, 2000: 50).

\footnotetext{
* Corresponding author
} 
According to Kotler and Armstrong (2008: 227), purchase decision is the stage of the decision process when the consumer actually purchases a product. As stated earlier, the students of University of Jember consist of various groups with different social and economic backgrounds, including the students of the Management Department, Faculty of Economics and Business. These differences can also influence students in making online purchases. Engaging in online transaction will facilitate the buyers in purchase process. For example, students could choose their desired products in a more flexible time. They do not have to visit the physical or offline stores. Product selection can be done anytime during the spare time.

Students of Management Department, Faculty of Economics and Business University of Jember can be described as the representative of the user of e-commerce systems, as the generation $\mathrm{Z}$ who were born and grown along with the development of the Internet. Therefore, this sample of this study was the students of Management Department, Faculty of Economics and Business, University of Jember. In the process of online shopping, student as an object must have certain considerations in terms of price, ease, information quality, safety, and trust. Based on the previous explanations, then, the aim of this study is to analyze the effect of price, ease of transaction, information quality, safety, and trust on online purchase decision.

\section{Method}

\section{Research Design}

This research is an explanatory research aims to explain the casual relationship between variables through hypothesis testing, using quantitative approach. The method used to analyze the data is multiple linier regression. Price, ease of transaction, information quality, safety, and trust act as the independent variables, while online purchase decision acts as the dependent variable.

\section{Data Type and Source}

The type of data used in this study is quantitative data. Source of data obtained from questionnaires distributed to the students of Department of Management, Faculty of Economics and Business, University of Jember.

\section{Population and Sample}

In general, for the correlational studies, the minimum number of samples to obtain good results is 30 , while in experimental studies, the minimum number of the sample is 15 from each experimental group, and for survey research, the minimum number of the sample is 100. Roscoe (1975) in Sekaran (2013: 295) provides a general reference for determining sample sizes as follows:

1. Sample size of more than 30 and less than 500 is appropriate for most studies.

2. If the sample is divided into subsamples (male/female, junior/senior, etc.), a minimum sample size of 30 for each category is appropriate.

3. In mutivariate research (including multiple regression analysis), the sample size should be 10 times bigger than the number of variables.

4. For simple experimental studies with strict experiment control, successful research is possible with small sample size between 10 to 20 .
According to these principles, the sample taken in this study is 100 respondents with the predetermined criteria (purposive sampling).

\section{Results and Discussions}

\section{Results}

\section{Characteristics of Respondents}

The following are descriptive statistics for each variable used in this study including data of respondent characteristics. Descriptive data of the respondents are as follows:

1. Characteristics of Respondents by Gender

Table 1. Gender of Respondent

\begin{tabular}{ccc}
\hline Gender & Amount & Percentage (\%) \\
\hline Male & 36 & 36 \\
Female & 64 & 64 \\
\hline Total & 100 & 100 \\
\hline
\end{tabular}

Table 1 shows that the number of respondents consist of 36 male respondents (36\%) and 64 female respondents (64\%). These results illustrate that the online consumers consisting of students of Department of Management, Faculty of Economics and Business, University of Jember are dominated by women.

2. Characteristics of Respondents Based on Visited Online Store (Marketplace)

Table 2. Respondent based on Visited Online Store

\begin{tabular}{ccc}
\hline Online Store & Amount & Percentage (\%) \\
\hline Tokopedia & 12 & 12 \\
Bukalapak & 19 & 19 \\
Shopee & 21 & 21 \\
Instagram & 15 & 15 \\
Lazada & 22 & 22 \\
Others & 11 & 11 \\
\hline Total & 100 & 100 \\
\hline
\end{tabular}

Table 2 shows that the respondents who purchased on Tokopedia were consisted of 12 people (12\%), while Bukalapak were consisted of 19 people (19\%), Shopee were consisted of 21 people (21\%), Instagram were consisted of 15 people $(15 \%)$, Lazada were consisted of 22 people $(22 \%)$, and other online stores were consisted of 11 people (11\%). These results illustrate that the most chosen platform is Lazada because it offers several advantages including diverse products, tempting discounts, and flexible payment methods, although some other online stores such as Shopee, Bukalapak, and Instagram were also chosen as the place to purchase products.

3. Characteristics of Respondents based onthe Type of Online Site

Table 3. Respondent based on the Online Site Type

\begin{tabular}{lcc}
\hline Online Site Type & Amount & Percentage (\%) \\
\hline Buying \& Selling & 42 & 42 \\
Forum & 23 & 23 \\
Trading & 20 & 20 \\
Kaskus & 15 & 15 \\
Others & 100 & 100 \\
\hline Total & & \\
\hline
\end{tabular}


Table 3 shows that respondents who used the online site for the buying and selling forum were consisted of 42 people $(42 \%)$, trading were consisted of 23 people $(23 \%)$, Kaskus were consisted of 20 people (20\%), and other purposes were consisted of 15 people (15\%). The buying and selling orum is the choice of most respondents because it offers certain promotions, uses a well-integrated system, various payment methods and pricing strategies that facilitate the ease and speed of transaction.

4. Characteristics of Respondents Based on Fashion Products

Table 4. Respondent based on Fashion Products

\begin{tabular}{ccc}
\hline Fashion & Amount & Percentage (\%) \\
Products & 27 & 27 \\
\hline Apparels & 23 & 23 \\
Shoes & 10 & 10 \\
Cosmetics & 21 & 21 \\
Bag & 19 & 19 \\
Hijab & 100 & 100 \\
\hline Total & & \\
\hline
\end{tabular}

Table 4 shows that respondents who bought apparel products were consisted of 27 people $(27 \%)$, shoes were consisted of 23 people $(23 \%)$, cosmetics were consisted of 10 people $(10 \%)$, bags were consisted of 21 people $(21 \%)$, and headscarves or hijab were 19 people $(19 \%)$. Then, it can be concluded that the biggest purchase is for the apparel products followed by shoes and bags. These results illustrate that the majority of sales occur in fashion products, also in line with the gender of respondents which is dominated by women.

5. Characteristics of Respondents Based on Electronic Media Used

Table 5 Respondents Electronic Media Used

\begin{tabular}{ccc}
\hline Electronic Media & Amount & Percentage (\%) \\
\hline PC/Laptop & 32 & 32 \\
Smartphone & 58 & 58 \\
Tablet & 10 & 10 \\
\hline Total & 100 & 100
\end{tabular}

Table 5 shows that respondents using PC/ Laptop were consisted of 32 people (32\%), smartphones were consisted of 58 people $(58 \%)$, and tablets were consisted of 10 people $(10 \%)$. Then, it can be stated that most respondents used their smartphone to buy online.

6. Characteristics of Respondents Based on Purchase Frequency

Table 6. Respondents based on Purchase Frequency

\begin{tabular}{lll}
\hline Purchase Frequency & Amount & Percentage $(\%)$ \\
\hline 2 times & 20 & 20 \\
$3-5$ times & 35 & 35 \\
$\geq 5$ times & 45 & 45 \\
\hline Total & 100 & 100 \\
\hline
\end{tabular}

Table 6 shows that the purchase frequency of 20 respondent are only 2 times $(20 \%)$, purchase frequency of 35 respondent are 3-5 times (35\%), while purchase frequency of 45 respondent are more than 5 times $(45 \%)$. Most respondents bought more than 5 times (45\%). This shows that respondents are actively engaged in online purchase.

7. Characteristics of Respondents Based on the Role of in Purchase Decisions

Table 7. Respondents Role in Purchase Decisions

\begin{tabular}{lll}
\hline $\begin{array}{l}\text { Role of } \\
\text { Respondents }\end{array}$ & Amount & Percentage (\%) \\
\hline Themselves & 55 & 55 \\
Parents & 12 & 12 \\
Friend & 23 & 23 \\
Other & 10 & 10 \\
\hline Total & 100 & 100 \\
\hline
\end{tabular}

Table 7 shows that when making any online purchase decisions, respondents act as themselves (55 people or 55\%), parents (12 people or $12 \%$ ), friends ( 23 people or $23 \%$ ), and others $(10$ people or $10 \%)$. Thus, it can be concluded that most online purchase decisions were made by respondent themselves, considering that respondents are students in adult age category who are capable to make decisions based on their own desires.

\section{Multiple Linear Regression Analysis}

Multiple regression analysis is used to measure the relationship between two variables or more and to show direction of the relationship of each variable used, both the dependent variable and the independent variable. The independent variable is assumed to be random which has a probabilistic distribution while the independent variable is assumed to have a fixed value in a repeated sampling. The results of multiple linear regression analysis are as follows:

Table 8. Multiple Linear Regression Analysis Results

\begin{tabular}{lccc}
\hline Variable & $\begin{array}{l}\text { Regression } \\
\text { Coefficient }\end{array}$ & Sig. & Description \\
\hline Constant & 0.024 & - & - \\
Price $\left(\mathrm{X}_{1}\right)$ & 0.162 & 0.047 & $\begin{array}{l}\text { Significant } \\
\text { Ease of Transaction }\end{array}$ \\
$\begin{array}{l}\left.\mathrm{X}_{2}\right) \\
\text { Information Quality }\end{array}$ & 0.172 & 0.011 & Significant \\
$\left(\mathrm{X}_{3}\right)$ & 0.201 & 0.005 & Significant \\
Safety $\left(\mathrm{X}_{4}\right)$ & 0.311 & 0.003 & Significant \\
Trust $\left(\mathrm{X}_{5}\right)$ & 0.199 & 0.009 & Significant \\
\hline
\end{tabular}

Based on Table 8 , the multiple linear regression equation result is as follows:

$\mathrm{Y}=0.024+0.162 \mathrm{X}_{1}+0.172 \mathrm{X}_{2}+0.201 \mathrm{X}_{3}+0.311 \mathrm{X}_{4}+$ $0.199 \mathrm{X}_{5}+\mathrm{e}$

From the equation model above, an explanation can be given as follows:

a. Constant Value

We get a constant value of 0.024 , which means that if the value of the independent variables of price $\left(\mathrm{X}_{1}\right)$, ease of transaction $\left(\mathrm{X}_{2}\right)$, information quality $\left(\mathrm{X}_{3}\right)$, safety $\left(\mathrm{X}_{4}\right)$, and trust $\left(\mathrm{X}_{5}\right)$ are equal to zero, then the value of purchase decision $(\mathrm{Y})$ is 0.024 .

b. Price $\left(\mathrm{X}_{1}\right)$

The coefficient value of price variable is 0.162 , which means that the direction of the relationship is positive 
(unidirectional), and this means that each increase of one unit of the variable will increase the purchase decision by 0.162 units.

c. Ease $\left(\mathrm{X}_{2}\right)$

The coefficient value of ease variable is 0.172 , which means that the direction of the relationship is positive (unidirectional), and this means that each increase of one unit of the variable will increase the purchase decision by 0.172 units.

\section{d. Information Quality $\left(\mathrm{X}_{3}\right)$}

The coefficient value of information quality variable is 0.201 , which means that the direction of the relationship is positive (unidirectional), and this means that each increase of one unit of the variable will increase the purchase decision by 0.201 units.

\section{e. Safety $\left(\mathrm{X}_{4}\right)$}

The coefficient value of safety variable is 0.311 , which means that the relationship is positive (unidirectional) and this means that each increase of one unit of the variable will increase the purchase decision by 0.311 units.

\section{f. Trust $\left(\mathrm{X}_{5}\right)$}

The coefficient value of trust variable is 0.199 , which means that the relationship is positive (unidirectional) and this means that every increase of one unit of the variable will increase the purchase decision by 0.199 units.

\section{Hypothesis testing}

\section{t test}

$t$ test is a test conducted to determine the significance of the partial effect of independent variables. The $t$ test results are as follows.

Table9. Results of $\mathrm{t}$ Test

\begin{tabular}{lc}
\hline \multicolumn{1}{c}{ Variable } & Sig. \\
\hline Price $\left(\mathrm{X}_{1}\right)$ & 0.047 \\
Ease of Transaction $\left(\mathrm{X}_{2}\right)$ & 0.011 \\
Information Quality $\left(\mathrm{X}_{3}\right)$ & 0.005 \\
Safety $\left(\mathrm{X}_{4}\right)$ & 0.003 \\
Trust $\left(\mathrm{X}_{5}\right)$ & 0.009 \\
\hline
\end{tabular}

Based on the data in Table 9, the effect of each independent variable on the dependent variable can be concluded as follows:

\section{The Effect of Price $\left(\mathrm{X}_{1}\right)$ on Purchase Decision (Y)}

Based on Table 8 , it can be seen that the significance level $(\alpha)$ of price variable $\left(X_{1}\right)$ is $0.474 \leq 0.05$. This means that price has a significant effect on purchase eecision $\left(\mathrm{H}_{1}\right.$ is accepted).

2. The Effect of Ease of Transaction $\left(\mathrm{X}_{2}\right)$ on Purchase Decision (Y)

Based on Table 8, it can be seen that the significance level $(\alpha)$ of ease of transaction variable $\left(X_{2}\right)$ is $0.011 \leq 0.05$. This means that ease of transaction has a significant effect on purchase decision $\left(\mathrm{H}_{2}\right.$ is accepted).

3. The Effect of Information Quality $\left(\mathrm{X}_{3}\right)$ on Purchase Decision (Y)

Based on Table 8, it can be seen that the significance level of $(\alpha)$ information quality variable $\left(\mathrm{X}_{3}\right)$ is $0.005 \leq 0.05$. This means that the information qualityhas a significant effect on purchase decision $\left(\mathrm{H}_{3}\right.$ is accepted).

4. The Effect of Safety $\left(\mathrm{X}_{4}\right)$ on Purchase Decision (Y)

Based on Table 8 , it can be seen that the significance level $(\alpha)$ of safety variable $\left(\mathrm{X}_{4}\right)$ is $0.003 \leq 0.05$. This means thatsafety has a significant effect on purchase decision $\left(\mathrm{H}_{4}\right.$ is accepted)

5. The Effect of Trust $\left(\mathrm{X}_{5}\right)$ on Purchase Decision (Y)

Based on Table 8 , it can be seen that the significance level $(\alpha)$ of trust variable $\left(\mathrm{X}_{5}\right)$ is $0.009 \leq 0.05$ This means that trust has a significant effect on purchase decision $\left(\mathrm{H}_{5}\right.$ is accepted)

\section{F test}

F test is a test to determine the simultaneous effect of the independent variables, namely $\mathrm{X}_{1} \mathrm{X}_{2} \mathrm{X}_{3} \mathrm{X}_{4} \mathrm{X}_{5}$ on dependent variable, which is $\mathrm{Y}$. The results of the $\mathrm{F}$ test can be seen in Table 10 below.

Table 10. Results of F Test

\begin{tabular}{cc}
\hline Variable & Sig. \\
\hline Residual & $0.000^{\mathrm{b}}$ \\
\hline
\end{tabular}

Based on Table 9 above, the first model has a significance value of 0.000 or less than 0.05 , then, it can be stated that the independent variables affect dependent variable simultaneously.

\section{Coefficient of Determination $\left(\mathrm{R}^{2}\right)$}

Coefficient of determination test is used to explain the proportion of the dependent variable that can be explained by the independent variable. Coefficient of determination value

range from $0 \leq R^{2} \leq 1$. A small value of $R^{2}$ means that the ability of the independent variables to explain the dependent variable is very limited. A value close to one means that the independent variable provides almost all the information needed to predict the dependent variable. Coefficient of Determination test results are as follows.

Table 11. $\mathrm{R}^{2}$ Test Results

\begin{tabular}{ccc}
\hline $\mathrm{R}$ & $\mathrm{R}$ Square & Adjusted R Square \\
\hline 0.891 & 0.795 & 0.784 \\
\hline
\end{tabular}

Based on Table 11, the model has an adjusted R Square value of 0.784 . This shows that the dependent variable of online purchase decision is able to be explained by the independent variables, namely price $\left(\mathrm{X}_{1}\right)$, ease of transaction $\left(\mathrm{X}_{2}\right)$, information quality $\left(\mathrm{X}_{3}\right)$, safety $\left(\mathrm{X}_{4}\right)$, and trust $\left(\mathrm{X}_{5}\right)$ of $78.4 \%$. This value indicates that all independent variables affect $78.4 \%$ of the dependent variable, while the rest, or $21.6 \%$, are influenced by other variables outside of the model used in this study.

\section{Discussions}

\section{The Effect of Price on Online Purchase Decisions}

The results of multiple linear regression analysis show that price has a significant effect on online purchase decision. The relationship shown by the regression coefficient is positive, meaning that the more appropriate the price, the higher the possibility to make online purchase decision. The result of $t$ test of the first hypothesis $\left(\mathrm{H}_{1}\right)$ shows that the price affects online purchase decision with the significance level of 0.047 . The significance level obtained is smaller than $0.05(\alpha)$. Thus, 
it is concluded $\mathrm{H}_{1}$ is accepted and this means that price significantly affects online purchase decision.

\section{The Effect of Ease of Transaction on Online Purchase Decision}

The results of the multiple linear regression analysis show ease of transaction has a significant effect on online purchase decision. The relationship shown by the regression coefficient is positive, meaning that the higher the ease of transaction level, the higher the possibility to make online purchase decision. In other words, the ease of transaction provided by the online store to make consumers feel happy during the online transaction, the more likely the consumers to make purchases. The results of $t$ test analysis of the second hypothesis $\left(\mathrm{H}_{2}\right)$ show that the significance value is 0.011 or smaller than $0.05(\alpha)$. Then, this research concludes that ease of transaction significantly affects online purchase decision.

\section{The Effect of Information Quality on Online Purchase Decision}

The results of multiple linear regression analysis show that information quality has a significant effect on online purchase decision. The relationship shown by the regression coefficient is positive, meaning that the higher the quality of information, the higher the possibility to make online purchase decision. In other words, the quality of the information provided makes consumers feel happy and encourages them to make purchases. The t-test analysis result of the third hypothesis $\left(\mathrm{H}_{3}\right)$ shows that the significance level value is 0.005 or smaller than $0.05(\alpha)$. Then, the conclusion that can be drawn is the third hypothesis $\left(\mathrm{H}_{3}\right)$ is accepted, which means that information quality significantly affects online purchase decision.

\section{The Effect of Safety on Online Purchase Decision}

The results of the multiple linear regression analysis indicate safety has a significant effect on online purchase decision. The relationship shown by the regression coefficient is positive, meaning that the higher the safety during online transaction, the higher the possibility to make online purchase decision. In other words, the higher the level of safety provided to make consumers feel safe, calm, and happy, the more they are encouraged to make purchases. Referring to the result of t-test analysis of the fourth hypothesis $\left(\mathrm{H}_{4}\right)$, the value of the level of significance is 0.003 or smaller than 0.05 $(\alpha)$. Then, the conclusion is that the fourth hypothesis $\left(\mathrm{H}_{4}\right)$ is accepted. It means that safety significantly affects online purchase decision.

\section{The Effect of Trust on Online purchase decision}

The results of multiple linear regression analysis shows that trust has a significant effect on online purchase decision. The relationship shown by the regression coefficient is positive, meaning that the higher the trust, the higher the possibility to make online purchase decision. Then, it can be stated that the higher level of trust will make consumers feel safe and happy that encourages them to make purchases. The result of t-test analysis of the fifth hypothesis $\left(\mathrm{H}_{5}\right)$ shows that the significance level value is 0.009 or smaller than $0.05(\alpha)$. Then, this research concludes that the fifth hypothesis $\left(\mathrm{H}_{5}\right)$ is accepted, which means that trust significantly affects online purchase decision.

\section{The Effect of Price, Ease of Transaction, Information Quality, Safety, and Trust on Online Purchase Decision}

According to the results of F-test of the sixth hypothesis $\left(\mathrm{H}_{6}\right)$, the significance level value is 0.000 or smaller than $0.05(\alpha)$. Then, we can conclude that the sixth hypothesis $\left(\mathrm{H}_{6}\right)$ is accepted, which means that price, ease of transaction, information quality, safety, and trust affect the online purchase decision simultaneously.

\section{Conclusion}

Based on the results and discussion, it can be concluded that price has a significant positive effect on online purchasing decision, which means that the more appropriate the price, the more likely for the consumers to make online purchase decision. Ease of transaction has a significant positive effect on online purchasing decision. Therefore, the easier the online transaction, the more consumers eager to make decision to purchase. Information quality has a significant positive effect on online purchasing decision, which means that the more relevant, valid, and appropriate the information provided, the more likely consumers make purchase decision. Safety has a significant positive effect on online purchase decision, which means that consumer seek for high safety level when they engage in any online purchase decisions. Trust has a significant positive effect on online purchasing decision. Thus, the higher the level of consumer trust, the higher the possibility to make online purchase decision. Simultaneously, appropriate price, ease of transaction, good information quality, good safety, and high level of trust will encourage consumers in making decision to purchase online.

\section{Thank You Note}

Thank you to all respondents for their participation in this study and to those who have helped in completing this research.

\section{References}

Kertajaya, Hermawan. 2003. Marketing Mix. Jakarta: PT. Gramedia Pustaka Utama

Jarvenpaa, S. L., Tractinsky, N., and Vitale, M. 2000. Consumer Trust in an Internet Store. Information Technology and Management, 1: 45-71.

Jogiyanto Hartono. 2007. Analisis dan Desain Sistem Informasi. Yogyakarta: Penerbit ANDI

Kotler, Philip. 2011. Manajemen Pemasaran di Indonesia: Analisis, Perencanaan, Implementasi dan Pengendalian. Jakarta: Salemba Empat

Kotler, Phillip dan Gary Amstrong. 2008. Prinsip-Prinsip Pemasaran, jilid 2, edisi ke-8, Jakarta : Penerbit Erlangga

Luthfiya, J. 2014. Pengaruh Pemasaran Online Terhadap Keputusan Pembelian Pada Siswa/I SMA Yayasan Pendidikan Harapan 3 Medan. Skripsi. Universitas Sumatera Utara

Park, Chung-Hoon., and Young-Gul Kim., 2006, The Effect of Information Satisfaction and Relational Benefit on Consumers Online Site Commitmennts. Journal of Electronic Commerce in Organizations, 4 (1), hal. 70-90.

Prapti Antarwiyati, Agus L N, dan Hadri K. 2010. Determinan Electronic Loyalty (e-Loyalty) Pada Website", Jurnal Akuntansi dan Auditing Indonesia, 14 (1): 1-21.

Sekaran, Uma dan Roger Bougie. 2013. Metode Penelitian untuk Bisnis: Pendekatan Pengembangan Keahlian, Edisi 6 buku 2. Jakarta : Salemba Empat. 